A

\title{
A Case Study: Empowering rural women as a successful entrepreneur - through Krishi Vigyan Kendra
}

\author{
GEETA P. CHANNAL, Y.K. KOTIKAL AND P.S. PATTAR
}

Article Chronicle : Received :

30.05.2017;

Accepted :

22.07.2017

KeY Words :

Empowering rural women, Selling assets, Farming
Author for correspondence :

GEETA P. CHANNAL

Krishi Vigyan Kendra (UAS), BAGALKOT (KARNATAKA) INDIA

See end of the article for authors' affiliations
How to cite this article : Channal, Geeta P., Kotikal, Y.K. and Pattar, P.S. (2017). Empowering rural women as a successful entrepreneur - through Krishi Vigyan Kendra. Agric. Update, 12(3): 498-501; DOI : 10.15740/HAS/ AU/12.3/498-501.

\section{BACKGROUND AND OBJECTIVES}

Exposure of women to income earning activities strengthens her economic role, increases her ability to contribute income to family and gives experience and selfconfidence in the public sphere, increased income controlled by women helps them to obtain a voice and vote in:

- Household decisions such as domestic well-being. For instance, women tend to use income clout for more equitable decisions about their childrens diet, education and health.

- Economic decisions such as acquiring, allocating, and selling assets.

- Fertility decisions: economically empowered women tend to have fewer children

- Land use and conservation decisions wherein rural women tend to favor sustainable environmental practices since they are usually the ones that collect the families' natural resources such as water and fuel wood.

Krishi Vigyan Kendras, were started in the country with an objective to transfer the latest technologies and to improve the socioeconomic status of the farming community. The KVK at Bagalkot was established under University of Agricultural Sciences, Dharwad in the year 2005. The district falls in the Northern dry zone of Karnataka having six blocks namely Badami, Bagalkot, Hunagund, Mudhol, Jamakhandi and Bilagi. One of the important mandates of KVK is to conduct on campus, off campus and vocational training to farmers, farm women and rural youths for generating self employment. This paper deals with the success stories of KVK Bagalkot in fulfilling this mandate with special reference to women.

\section{RESOURCES AND METHOdS}

On campus and vocational trainings were organized by KVK Bagalkot since its inception in 2005. A list of training programmes conducted on income generation activities were as under. Trained women were consulted to know whether they had adopted the technologies. Some of the most successful adopters who have taken up the enterprise 